\title{
MGMT promoter methylation in gliomas- assessment by pyrosequencing and quantitative methylation-specific PCR
}

\author{
Annette Bentsen Håvik ${ }^{1,2,3,4}$, Petter Brandal ${ }^{1,3,5^{*}}$, Hilde Honne ${ }^{2,3}$, Hanne-Sofie Spenning Dahlback ${ }^{1,3,4}$, David Scheie ${ }^{6}$, \\ Merete Hektoen ${ }^{2,3}$, Torstein Ragnar Meling ${ }^{7}$, Eirik Helseth ${ }^{4,8}$, Sverre Heim ${ }^{1,3,4}$, Ragnhild A Lothe ${ }^{2,3,9}$ and \\ Guro Elisabeth Lind ${ }^{2,3}$
}

\begin{abstract}
Background: Methylation of the $0^{6}$-methylguanine-DNA methyltransferase (MGMT) gene promoter is a favorable prognostic factor in glioblastoma patients. However, reported methylation frequencies vary significantly partly due to lack of consensus in the choice of analytical method.

Method: We examined 35 low- and 99 high-grade gliomas using quantitative methylation specific PCR (qMSP) and pyrosequencing. Gene expression level of MGMT was analyzed by RT-PCR.

Results: When examined by qMSP, $26 \%$ of low-grade and 37\% of high-grade gliomas were found to be methylated, whereas $97 \%$ of low-grade and 55\% of high-grade gliomas were found methylated by pyrosequencing. The average MGMT gene expression level was significantly lower in the group of patients with a methylated promoter independent of method used for methylation detection. Primary glioblastoma patients with a methylated MGMT promoter (as evaluated by both methylation detection methods) had approximately 5 months longer median survival compared to patients with an unmethylated promoter (log-rank test; pyrosequencing $P=$ .02 , qMSP $P=.06$ ). One third of the analyzed samples had conflicting methylation results when comparing the data from the GMSP and pyrosequencing. The overall survival analysis shows that these patients have an intermediate prognosis between the groups with concordant MGMT promoter methylation results when comparing the two methods.
\end{abstract}

Conclusion: In our opinion, MGMT promoter methylation analysis gives sufficient prognostic information to merit its inclusion in the standard management of patients with high-grade gliomas, and in this study pyrosequencing came across as the better analytical method.

Keywords: Glioma, Glioblastoma, MGMT, Methylation, Gene expression, Low-grade glioma, High-grade gliomas, Pyrosequencing, qMSP, RT-PCR

\section{Background}

Gliomas are histologically divided into several subgroups including astrocytomas, oligodendrogliomas, and oligoastrocytomas and are graded from I to IV according to the WHO classification [1]. Prognosis is highly variable depending on histopathology, grade,

\footnotetext{
* Correspondence: petter.brandal@ous-hf.no

'Section for Cancer Cytogenetics, Institute for Medical Informatics, Oslo University Hospital-The Norwegian Radium Hospital, P.O. Box 4950 Nydalen, $\mathrm{N}-0424$ Oslo, Norway

Full list of author information is available at the end of the article
}

patient age, and genetic tumor factors such as the presence of a $1 \mathrm{p} / 19 \mathrm{q}$ co-deletion, IDH1 and IDH2 mutations, and MGMT promoter methylation $[1,2]$. The most common glioma subtype in adults is glioblastoma (GBM) with an annual incidence of 3-4/100 000 [1]. This is also the subgroup with the least favorable prognosis. In 2005, Stupp and coworkers reported a 2.5 months increase in median overall survival for GBM patients when adding concomitant and adjuvant temozolomide (TMZ) to postoperative radiotherapy [3]. It should be noted, however, that clinical trials tend to

\section{Biomed Central}

(c) 2012 Håvik et al; licensee BioMed Central Ltd. This is an Open Access article distributed under the terms of the Creative Commons Attribution License (http://creativecommons.org/licenses/by/2.0), which permits unrestricted use, distribution, and reproduction in any medium, provided the original work is properly cited. 
report higher median overall survival rates than retrospective studies, possibly due to selection bias [1]. Therefore, it is not surprising that a retrospective population-based Norwegian study reported a lower median overall survival for GBM patients (9.9 months) than that of the Stupp study patients (14.6 months and 12.1 months) $[3,4]$.

About $5 \%$ of the DNA methylation induced by TMZ is located at the $\mathrm{O}^{6}$-position of guanine and methylation in this position is considered to be the main contributor to the cytotoxic effect [5-7]. The DNA repair enzyme O-6-methylguanine-DNA methyltransferase (MGMT) removes methyl groups from the $\mathrm{O}^{6}$-position of guanine and the expression of MGMT is therefore thought to inhibit the cytotoxic effect of TMZ $[5,6]$. Even though the first studies suggesting that MGMT promoter hypermethylation was an important molecular marker in high-grade gliomas were published almost a decade ago [8-10], the extent of its positive prognostic and predictive value in the different grades of gliomas remains to be determined [11]. Further, though several studies indicate that MGMT promoter methylation is a prognostic marker [11], there is no clear consensus as to which detection method should be preferred or what constitutes optimal threshold values for scoring samples as methylation positive. As a result, a wide range of reported glioma MGMT methylation frequencies can be seen (Additional file 1: Tables S1 and S2) [11]. We have used two independent quantitative methylation detection methods, quantitative methylation specific polymerase chain reaction ( $\mathrm{qMSP}$ ) and pyrosequencing, to analyze a large series of gliomas. We also analyzed the gene expression level of MGMT in the majority of these samples. To illustrate the variability in methylation frequencies and methylation detection methods, we systemized publications reporting $M G M T$ promoter methylation in a tabular overview (Additional file 1: Tables S1 and S2).

\section{Materials and methods}

\section{Patients and samples}

Tumor samples from 134 glioma patients (diffuse astrocytoma WHO grade II $(\mathrm{n}=10)$, oligodendroglioma WHO grade II $(\mathrm{n}=6)$, oligoastrocytoma WHO grade II $(\mathrm{n}=17)$, low-grade neuroepithelial tumour not otherwise specified $(\mathrm{n}=2)$, anaplastic astrocytoma WHO grade III $(\mathrm{n}=4)$, anaplastic oligodendroglioma WHO grade III $(n=6)$, anaplastic oligoastrocytoma WHO grade III $(n=3)$, glioblastoma WHO grade IV $(\mathrm{n}=86))$ and four meningioma patients who underwent surgery at the Department of Neurosurgery (Oslo University Hospital) between January 2005 and January 2009 were included in this study. The meningioma samples served as MGMT promoter methylation negative controls [12]. Histological diagnoses were reviewed by an expert neuropathologist (author D.S.). Patients alive were included following written, informed consent whereas permission to include deceased patients was obtained from The National Health Authorities. The study was approved by the Regional Ethics Committee (S-06046) as well as the Institutional Study Board.

\section{DNA isolation and bisulfite conversion}

DNA was extracted from fresh frozen tissue using a standard phenol-chloroform procedure and its quantity and quality was measured using a NanoDrop ND-1000 Spectrophotometer (Thermo Fisher Scientific). Unmethylated cytosine residues were converted to uracil by bisulfite treatment of $1.3 \mu \mathrm{g}$ DNA using the EpiTect Bisulfite Kit (Qiagen) according to the manufacturers' protocol. After conversion, DNA was eluted in buffer (Qiagen) to a final concentration of $30 \mathrm{ng} / \mu \mathrm{l}$.

\section{Quantitative methylation specific polymerase chain reaction}

MGMT promoter methylation was quantitatively assessed by two qMSP assays, each covering $11 \mathrm{CpG}$ sites (CpGs). The two assays analyzed CpGs in partially overlapping regions (Additional file 1: Figure S1), but detected methylation on opposite DNA strands. Primers (Medprobe) and 6-FAM labeled minor groove binder (MGB) probes (Applied Biosystems, Life Technologies) were modified from two previously reported assays $[13,14]$ to adjust the melting temperature to $60^{\circ} \mathrm{C}$ for primers and $70^{\circ} \mathrm{C}$ for probes. Amplification of a part of the $A L U$-element (ALU C4) was used for normalization [15]. Primers and probe sequences are listed in Table 1. Amplification reactions were carried out in triplicate in 384 well plates using the $7900 \mathrm{HT}$ Fast-Real time PCR machine (Applied Biosystems, Life Technologies). The total reaction volume was $20 \mu \mathrm{l}$ and contained $30 \mathrm{ng}$ bisulfite treated DNA, $0.9 \mu \mathrm{M}$ forward and reverse primer, $0.2 \mu \mathrm{M}$ probe, and $1 \times$ TaqMan Universal PCR Mastermix (No AmpErase UNG; Applied Biosystems, Life Technologies). The PCR program included initial denaturation at $95^{\circ} \mathrm{C}$ for $10 \mathrm{~min}$ followed by 45 cycles of $95^{\circ} \mathrm{C}$ for $15 \mathrm{~s}$ and $60^{\circ} \mathrm{C}$ for $60 \mathrm{~s}$. Results were processed and exported using default settings in the software SDS 2.2.2 (Applied Biosystems, Life Technologies). Each plate included several non-template controls (water), an unmethylated control (bisulfite treated normal leukocyte DNA), and a methylated control (bisulfite converted in vitro methylated human DNA; Chemicon, Millipore). To quantitate the amount of fully methylated alleles in each reaction, a standard curve was generated for each plate using a serial dilution of the methylated control (32.5-0.052 ng). 
Table 1 Primers and probes used for quantitative methylation-specific polymerase chain reaction (qMSP)

\begin{tabular}{ll}
\hline Assay & Sequence \\
\hline MGMT qMSP $^{\mathbf{a}}$ & \\
\hline Forward primer & GCGTTCGACGTTCGTAGGT \\
\hline Reverse primer & CACTCTTCCGAAAACGAAACG \\
\hline Probe & 6FAM-AAACGATACGCACCGCGA-MGB \\
\hline${\text { MGMT_1 } \mathbf{q M S P}{ }^{\mathbf{b}}}$ \\
\hline Forward primer & CGAATATACTAAAACAACCCGCG \\
\hline Reverse primer & TITTTCGGGAGCGAGGC \\
\hline Probe & 6FAM-CGCGATACGCACCGTTACG-MGB
\end{tabular}

ALU qMSP ${ }^{c}$

Forward primer GGTTAGGTATAGTGGTTTATATTTGTAATTTAGTA

Reverse primer $\quad$ ATTAACTAAACTAATCTTAAACTCCTAACCTCA

Probe 6FAM-CCTACCTTAACCTCCC-MGB

Abbreviations: $q M S P$, quantitative methylation-specific polymerase chain reaction; $M G B$, minor groove binder

a) Modified after Rivera et al., Neuro Oncol. (2010)

b) Modified after Hoque et al., J. Natl. Cancer Inst. (2006)

c) Weisenberger et al., Nucleic Acids Res. (2005)

Samples with a Ct-value above 35 were censored (resulting in a quantity of 0 ). The percentage of methylated reference (PMR) was calculated for each sample from the median quantity value from the triplicates by dividing the MGMT/ALU quantity ratio in the target by the MGMT/ALU quantity ratio in the methylated control, and multiplying by 100 . A threshold value for scoring methylation positive samples was defined based on the qMSP result of four meningiomas, which all had PMR values of zero in both qMSP assays. Only samples with a PMR value above zero in both assays were scored as methylation positive. Representative PCR products from both reactions were sequenced in order to verify the fragment identity.

\section{Pyrosequencing}

Five CpG sites in the MGMT promoter were analyzed by pyrosequencing using the PyroMark MD System (Qiagen). Bisulfite treated DNA was amplified in a PCR reaction using primers from the PyroMark Q96 CpG MGMT kit (part number 972032, Qiagen). In addition to the samples, each run included a non-template control (water), an unmethylated control (bisulfite treated normal leukocyte DNA), and a methylated control (bisulfite converted in vitro methylated human DNA). The amplification was carried out in 96-well plates and the PCR reaction and cycling conditions were according to the kit manual. Subsequent sample preparation and pyrosequencing was performed as described in the PyroMark MD Sample Prep Guidelines. In brief, the double stranded PCR products were denatured in $\mathrm{NaOH}$ and washed before a sequencing primer was annealed. The pyrosequencing reaction starts from the 3 '-end of the sequencing primer. Nucleotides (A, T, C, and G) were dispensed into each sample well, one at a time. Whenever a base complementary to the base in the PCR product is added, it is incorporated into the growing DNA strand, resulting in an enzymatic cascade and production of light. The light intensity is measured at each dispensation and presented graphically in a pyrogram. The dispensation order was generated automatically by the Pyromark CpG Software 1.0.11 and modified according to recommendations by the provider (two dispensations added). The dispensation order was GTCGCTTAGTCTGTTCGTATCAGTCGTCA (extra dispensations in bold). The extra $C$ dispensation in the beginning of the sequence served as a bisulfite control. The additional $\mathrm{T}$ dispensation was included to remove background noise in the following $\mathrm{CpG}$ site, thus the peak was excluded as a reference peak in data analysis. The minimal signal value was set to 100 as recommended in the Pyromark CpG Software user manual. Apart from these changes, the results were analyzed using default software settings.

The pyrosequencing threshold was determined from the mean methylation value in the five analyzed $\mathrm{CpG}$ sites and the mean standard deviation $(\mathrm{X}+2 \mathrm{SD})$ in the four meningiomas. Glioma samples were scored as methylation positive by pyrosequencing if all five $\mathrm{CpG}$ sites had methylation values higher than the resulting threshold of $2.68 \%$.

\section{MGMT expression analysis by real-time reverse transcriptase PCR}

Total RNA was extracted from 81 of the 134 glioma samples. The tissue samples were stored frozen in RNAlater and total RNA was extracted using a standard TRIzol protocol. RNA quantity and integrity were examined using a NanoDrop ND-1000 Spectrophotometer (Thermo Fisher Scientific) and an Agilent BioAnalyzer 2100 (Agilent Technologies), respectively. Total RNA was reverse transcribed using cDNA by random hexamer primers and the High Capacity cDNA Reverse Transcription Kit (Applied Biosystems, Life Technologies) according to the manufacturers' protocol. The realtime PCR was carried out in triplicates in 384 well plates using the $7900 \mathrm{HT}$ Fast-Real time PCR machine (Applied Biosystems, Life Technologies). The total reaction volume was $20 \mu \mathrm{l}$ and contained $20 \mathrm{ng}$ cDNA, $1 \times$ TaqMan Universal PCR Mastermix (Applied Biosystems, Life Technologies), and 1× TaqMan Gene Expression assay (Applied Biosystems, Life Technologies; see below). The PCR was run at $50^{\circ} \mathrm{C}$ for $2 \mathrm{~min}, 95^{\circ} \mathrm{C}$ for 10 min, and 40 cycles of $95^{\circ} \mathrm{C}$ for $15 \mathrm{~s}$ and $60^{\circ} \mathrm{C}$ for $60 \mathrm{~s}$. Each sample was analyzed with two different TaqMan Gene Expression Assays for MGMT (Hs01037698_m1 
and Hs00172470_m1; part number 4331182, Applied Biosystems, Life Technologies) as well as two endogenous controls ( $A C T B$; part number 4352935E, and GUSB part number 4333767 F, Applied Biosystems, Life Technologies). The median result in each triplicate was used for data analysis.

Each plate included several non-template controls and a standard curve generated by a serial dilution of total cDNA reverse transcribed from Universal Human Reference RNA (Stratagene, Agilent Technologies). Ct-values were determined automatically with the default settings in the software SDS 2.2.2 (Applied Biosystems, Life Technologies) and converted to quantity using the standard curves. Samples with a Ct-value above 35 were censored. The quantity was normalized by dividing the quantity of $M G M T$ expression by the average quantity of $A C T B$ and GUSB.

\section{Statistical analyses}

Statistical analyses were performed in SPSS 16.0. (SPSS Inc.). We used McNemar's chi-squared test for comparison of the two methylation detection methods and Kruskal-Wallis' rank sum test to determine potential differences in methylation level between high- and lowgrade gliomas. Overall survival analysis was performed using the Kaplan-Meier procedure and included all primary glioblastoma patients who were treated with standard radiotherapy $(2 \mathrm{~Gy} \times 30)$ and concomitant, and in some cases adjuvant, TMZ $(n=58)$. Patients' date of death was collected from the National Population Register. Survival was calculated from date of first surgery. Log-rank test was based on 24 months overall survival. T-tests for independent samples were performed to compare average gene expression of MGMT in samples with versus samples without a methylated MGMT promoter. All $P$-values < 0.05 were considered statistically significant.

\section{Results}

\section{MGMT promoter methylation status}

The results of the two methylation detection methods, qMSP and pyrosequencing, were compared (McNemar's chi-squared; $P<.001)$. Using pyrosequencing, $66 \%$ of the samples were scored as methylation positive, whereas qMSP analysis resulted in $34 \%$ positive samples. The percentage of methylated samples, the interquartile range of the PMR values, and pyrosequencing results are summarized in Table 2. All glioma samples scored as methylated by qMSP were also found methylated by pyrosequencing $(n=46)$. Likewise, another 46 glioma samples scored as unmethylated by qMSP were also found unmethylated by pyrosequencing. A total of 42 glioma samples were scored as methylated by pyrosequencing and unmethylated by qMSP. All samples with PMR values above zero in one of the two qMSP assays
( $\mathrm{n}=16)$ were detected as methylation positive by pyrosequencing. The methylation levels (amount of methylation) determined by pyrosequencing and the MGMT_1 qMSP assay were significantly lower in methylated lowgrade gliomas compared to methylated high-grade gliomas, $P=.003$ and $P=.018$, respectively. However, the difference was not statistically significant when testing methylation levels determined by the MGMT qMSP assay $(P=.208)$.

\section{MGMT promoter methylation status and survival of primary glioblastoma patients}

Regardless of the method used to determine methylation status, the 24-months overall survival curves for primary glioblastoma patients receiving standard radiotherapy and at least concomitant TMZ displayed a trend towards better survival in the patient group with methylated MGMT promoter than in the patient group with unmethylated MGMT promoter (log-rank test, $P=.06$ and $P=.02$ for qMSP and pyrosequencing, respectively; Figure $1 \mathrm{~A}$ and $1 \mathrm{~B})$. Median overall survival in the patient group with methylated MGMT promoter was about 5 months longer than the median overall survival for patients with an unmethylated MGMT promoter. Patient characteristics and results from the overall survival analysis are summarized in Table 3. Overall survival for patients with conflicting MGMT promoter methylation results as assessed by qMSP and pyrosequencing was intermediate when compared to the two groups of patients with concordant results (Figure 1C).

\section{MGMT gene expression in samples with and without MGMT promoter methylation}

The average gene expression value in samples with methylated MGMT promoter was significantly lower than the average gene expression value in samples with unmethylated MGMT promoter $(P<0.01)$ regardless of methylation detection method (Figure 2). The difference was statistically significant also after elimination of the most evident outlier. The scatter plots (Figure 3) show the gene expression level in samples where we also had access to karyotypic and/or CGH data [16,17] (author H-S. S. Dahlback, unpublished data) $(\mathrm{n}=52)$.

\section{Discussion}

Reported frequencies of MGMT promoter methylation in subgroups of gliomas vary considerably, as shown in Additional file 1: Tables S1 and S2. Various methylation detection methods and different primer sets and threshold values have been used. In the present study, we report $M G M T$ promoter methylation frequencies in gliomas determined by qMSP (low-grade gliomas 26\% and high-grade gliomas 37\%) as well as by pyrosequencing (low-grade gliomas $97 \%$ and high-grade gliomas 
Table 2 MGMT methylation frequencies and methylation level in methylated glioma samples

\begin{tabular}{|c|c|c|c|c|c|}
\hline \multirow[t]{4}{*}{ Group } & \multicolumn{3}{|c|}{ qMSP results } & \multicolumn{2}{|c|}{ Pyrosequencing results } \\
\hline & \multirow[b]{3}{*}{ Methylated samples } & \multirow{2}{*}{\multicolumn{2}{|c|}{$\begin{array}{c}\text { Median and IQR } \\
\text { calculated from PMR }\end{array}$}} & \multirow[b]{3}{*}{ Methylated samples } & \multirow{3}{*}{$\begin{array}{c}\text { Median and IQR } \\
\text { calculated from } \\
\text { mean CpG methylation }\end{array}$} \\
\hline & & & & & \\
\hline & & $\begin{array}{l}\text { MGMT } \\
\text { assay }\end{array}$ & $\begin{array}{l}\text { MGMT_1 } \\
\text { assay }\end{array}$ & & \\
\hline Low-grade gliomas & $\begin{array}{c}9 / 35 \\
(25.7 \%)\end{array}$ & $\begin{array}{c}3.30 \\
(0.78-19.66)\end{array}$ & $\begin{array}{c}0.50 \\
(0.29-2.57)\end{array}$ & $\begin{array}{c}34 / 35 \\
(97.1 \%)\end{array}$ & $\begin{array}{c}16.98 \\
(10.97-38.29)\end{array}$ \\
\hline $\begin{array}{l}\text { Astrocytoma } \\
\text { WHO grade ॥ }\end{array}$ & $\begin{array}{c}2 / 10 \\
(20.0 \%)\end{array}$ & $\begin{array}{c}1.19 \\
(0.85-1.54)\end{array}$ & $\begin{array}{c}0.30 \\
(0.29-0.30)\end{array}$ & $10 / 10(100.0 \%)$ & $\begin{array}{c}12.56 \\
(7.24-16.68)\end{array}$ \\
\hline $\begin{array}{l}\text { Oligodendroglioma } \\
\text { WHO grade II }\end{array}$ & $\begin{array}{c}1 / 6 \\
(16.7 \%)\end{array}$ & $\begin{array}{c}0.78 \\
-\end{array}$ & $\begin{array}{c}0.87 \\
-\end{array}$ & $\begin{array}{c}5 / 6 \\
(83.3 \%)\end{array}$ & $\begin{array}{c}29.51 \\
(24.23-33.17)\end{array}$ \\
\hline $\begin{array}{l}\text { Oligoastrocytoma } \\
\text { WHO grade II }\end{array}$ & $\begin{array}{c}6 / 17 \\
(35.3 \%)\end{array}$ & $\begin{array}{c}11.72 \\
(3.42-24.16)\end{array}$ & $\begin{array}{c}1.54 \\
(0.32-7.83)\end{array}$ & 17/17 (100.0\%) & $\begin{array}{c}24.90 \\
(14.41-47.52)\end{array}$ \\
\hline $\begin{array}{l}\text { Low-grade neuroepithelial tumours } \\
\text { (not otherwise specified) }\end{array}$ & $\begin{array}{c}0 / 2 \\
(0.0 \%)\end{array}$ & - & - & $\begin{array}{c}2 / 2 \\
(100.0 \%)\end{array}$ & $\begin{array}{c}6.83 \\
(5.33-8.32)\end{array}$ \\
\hline High-grade gliomas & $\begin{array}{c}37 / 99 \\
(37.4 \%)\end{array}$ & $\begin{array}{c}9.18 \\
(4.39-17.81)\end{array}$ & $\begin{array}{c}5.59 \\
(1.89-12.37)\end{array}$ & $\begin{array}{c}54 / 99 \\
(54.5 \%)\end{array}$ & $\begin{array}{c}47.14 \\
(18.50-62.87)\end{array}$ \\
\hline $\begin{array}{l}\text { Anaplastic astrocytoma } \\
\text { WHO grade III }\end{array}$ & $\begin{array}{c}1 / 4 \\
(25.0 \%)\end{array}$ & $\begin{array}{c}24.19 \\
-\end{array}$ & $\begin{array}{c}22.35 \\
-\end{array}$ & $\begin{array}{c}2 / 4 \\
(50.0 \%)\end{array}$ & $\begin{array}{c}55.82 \\
(52.95-58.70) \\
\end{array}$ \\
\hline $\begin{array}{l}\text { Anaplastic oligodendroglioma } \\
\text { WHO grade III }\end{array}$ & $\begin{array}{c}6 / 6 \\
(100.0 \%)\end{array}$ & $\begin{array}{c}19.30 \\
(7.71-54.53)\end{array}$ & $\begin{array}{c}11.61 \\
(6.68-16.09)\end{array}$ & $\begin{array}{c}6 / 6 \\
(100.0 \%)\end{array}$ & $\begin{array}{c}70.85 \\
(52.98-82.52)\end{array}$ \\
\hline $\begin{array}{l}\text { Anaplastic oligoastrocytoma } \\
\text { WHO grade III }\end{array}$ & $\begin{array}{c}1 / 3 \\
(33.3 \%)\end{array}$ & $\begin{array}{c}17.81 \\
-\end{array}$ & $\begin{array}{c}0.90 \\
-\end{array}$ & $\begin{array}{c}2 / 3 \\
(66.7 \%)\end{array}$ & $\begin{array}{c}52.99 \\
(48.03-57.94)\end{array}$ \\
\hline $\begin{array}{l}\text { Glioblastoma } \\
\text { WHO grade IV }\end{array}$ & $\begin{array}{l}29 / 86 \\
(33.7 \%)\end{array}$ & $\begin{array}{c}7.98 \\
(4.00-14.55)\end{array}$ & $\begin{array}{c}5.39 \\
(1.89-11.37)\end{array}$ & $\begin{array}{l}44 / 86 \\
(51.2 \%)\end{array}$ & $\begin{array}{c}43.31 \\
(12.05-61.04)\end{array}$ \\
\hline Primary glioblastoma & $\begin{array}{l}27 / 80 \\
(33.8 \%)\end{array}$ & $\begin{array}{c}8.67 \\
(3.85-15.33)\end{array}$ & $\begin{array}{c}5.59 \\
(1.80-11.48)\end{array}$ & $\begin{array}{l}40 / 80 \\
(50.0 \%)\end{array}$ & $\begin{array}{c}40.68 \\
(11.12-59.05)\end{array}$ \\
\hline Included in survival analysis ${ }^{\mathrm{a}}$ & $\begin{array}{c}19 / 58 \\
(32.8 \%)\end{array}$ & $\begin{array}{c}5.53 \\
(2.58-10.42)\end{array}$ & $\begin{array}{c}3.22 \\
(1.14-10.26)\end{array}$ & $\begin{array}{l}29 / 58 \\
(50.0 \%)\end{array}$ & $\begin{array}{c}34.88 \\
(10.64-48.73)\end{array}$ \\
\hline Secondary glioblastoma & $\begin{array}{c}2 / 6 \\
(33.3 \%)\end{array}$ & $\begin{array}{c}5.76 \\
(5.18-6.34) \\
\end{array}$ & $\begin{array}{c}2.75 \\
(2.41-3.08) \\
\end{array}$ & $\begin{array}{c}4 / 6 \\
(66.7 \%)\end{array}$ & $\begin{array}{c}55.26 \\
(42.67-63.93) \\
\end{array}$ \\
\hline All glioma samples & $\begin{array}{l}46 / 134 \\
(34.3 \%)\end{array}$ & $\begin{array}{c}8.33 \\
(3.40-18.55)\end{array}$ & $\begin{array}{c}4.36 \\
(0.88-11.54)\end{array}$ & $88 / 134$ (65.7\%) & $\begin{array}{c}34.03 \\
(12.42-54.83)\end{array}$ \\
\hline
\end{tabular}

Abbreviations: $P M R$, Percentage of methylated reference, $G M S P$, quantitative methylation specific $P C R, I Q R$, interquartile range

a)Primary glioblastoma patients treated with standard radiation and at least concomitant temozolomide

55\%). It should be noted that the CpG sites interrogated in the qMSP and pyrosequencing assays are only partially overlapping (Additional file 1: Figure S1), and caution should therefore be made when directly comparing the results. The $M G M T$ promoter is typically reported methylated in $30-60 \%$ of glioblastomas [11] and in 30$90 \%$ of low-grade gliomas $[12,18]$. Compared to these reports, our qMSP methylation frequencies are in the lower range whereas the pyrosequencing methylation frequencies are in the upper range.

The vast majority of previous studies of MGMT promoter methylation in gliomas have used gel based methylation-specific PCR (MSP), which is a qualitative and time-consuming method. The manual methylation scoring based on interpretation of gel band intensities will vary in stringency level between labs, which, in addition to the use of different primers, may in part explain some of the observed difference in results observed from MSP based studies. This is exemplified by two works using the same primer sets but reporting very different methylation frequencies of $23 \%$ and $44 \%$ in newly diagnosed glioblastoma samples $[19,20]$. In contrast to MSP, qMSP is a quantitative, standardized, high-throughput method which is easy to perform and the results are easy to evaluate. Thus, the method is more suitable for use in routine testing. To detect methylation by amplification of methylated alleles in MSP and qMSP, all CpG sites on the same DNA strand covered by the primers have to be methylated. Compared with traditional MSP, qMSP is even more conservative as it includes a methylation-specific probe and thereby typically covers more CpG sites that all have to be methylated. This may lower the sensitivity of the assay, but more importantly, increases the specificity, as underscored by Parella et al. who analyzed MGMT promoter methylation using both MSP and qMSP assays. In 


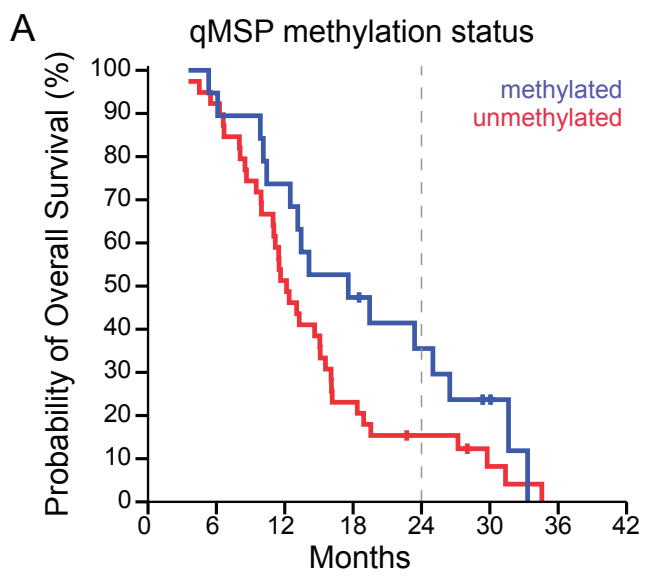

B

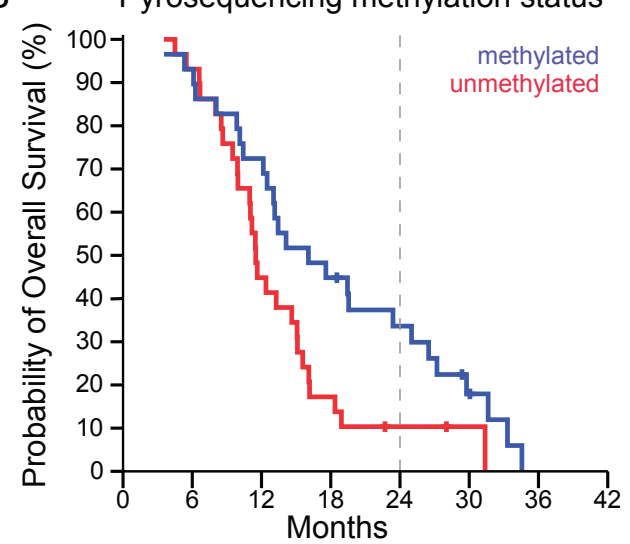

C

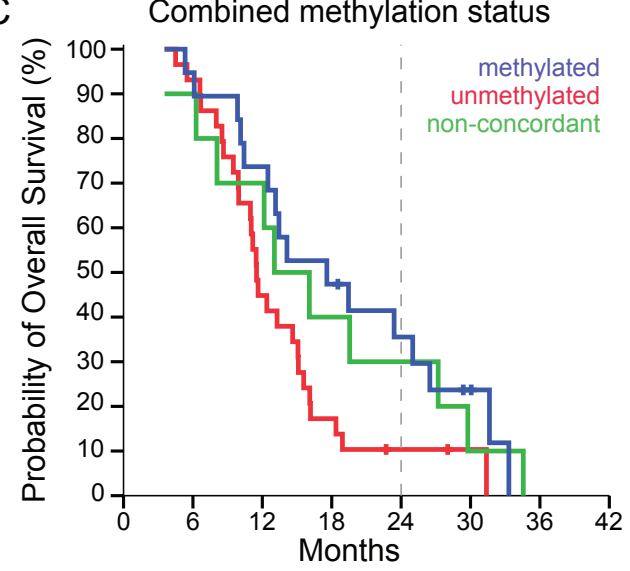

Figure 1 Overall survival in primary glioblastoma patients treated with standard radiotherapy and concomitant

temozolomide. (A) Methylation status based on results from qMSP. Blue line; methylated, red line; unmethylated. (B) Methylation status based on results from pyrosequencing. Blue line; methylated, red line; unmethylated. (C) Methylation status based on both qMSP and pyrosequencing results. Blue line; methylated in both methods, red line; unmethylated in both methods, green line; methylated in pyrosequencing assay and unmethylated in qMSP assay.

Abbreviation: GMSP, quantitative methylation specific PCR glioma samples the two methods showed good concordance, whereas the results from normal brain samples demonstrated that MSP may hold a higher risk of false positive results [21]. In the present study, we used two overlapping qMSP assays and only scored samples as methylated if they had a positive PMR value in both assays. The results from the two assays were generally overlapping. Of the 134 analyzed gliomas samples only 16 of them had conflicting methylation status from the qMSP assays. The PMR-values seemed to be somewhat higher in one of the qMSP assays. This is probably a result of the inclusion of different $\mathrm{CpG}$ sites in the two assays (Additional file 1: Figure S1). The conservative nature of the qMSP assay may explain why our qMSP methylation frequencies are in the lower range of previously reported MSP results $[11,12,18]$. One of the primer/probe sets used in the present study corresponds to the assay used by Parrella and coworkers [13,21]. The second qMSP assay is modified after a recent publication by Rivera et al. [14] who found MGMT promoter methylation in $24 \%$ of GBM patients, which is similar to the methylation frequency found by us.

As expected, the MGMT promoter methylation frequencies as measured by pyrosequencing were found to be in the upper range compared to previous MSP based findings. In contrast to MSP and qMSP, the pyrosequencing technique is able to detect low levels of methylation because methylation in each CpG site is measured independently of the methylation status in surrounding $\mathrm{CpG}$ sites. Indeed, our methylation frequency in high-grade gliomas (55\%) is highly concordant with the GBM methylation frequency recently determined in a pyrosequencing work by Dunn et al. (53\%) [22].

Choice of threshold values for scoring samples as methylation positive or not may also explain some of the differences observed in reported methylation frequencies. Ideally, the threshold value should be determined using a test series of a large number of normal tissue samples as well as tumor samples. The threshold value can thereafter be chosen to give a high sensitivity (with the risk of producing false positives) or a high specificity (with the risk of failing to identify all positive cases as such). We have used high-quality DNA extracted from fresh frozen tissue for all methylation analyses. In some neurooncology centers sampling of fresh frozen tissue is not a standard procedure, hence formalin-fixed paraffin embedded (FFPE) tissue is a frequently used DNA source. All MGMT promoter fragments amplified in the present study are short (qMSPs $83-119$ bp and pyrosequencing $\sim 100 \mathrm{bp}$ ) and will most likely be amplifiable also in DNA extracted from FFPE tissue. Lacking access to normal brain tissue, we used four benign meningioma samples to set the threshold 
Table 3 Patient characteristics and results of survival analysis for primary glioblastoma patients when stratified by MGMT methylation status

\begin{tabular}{|c|c|c|c|c|c|}
\hline \multirow[t]{3}{*}{ Overall survival } & \multirow{3}{*}{ Total } & \multicolumn{4}{|c|}{ MGMT methylation status } \\
\hline & & \multicolumn{2}{|c|}{ qMSP } & \multicolumn{2}{|c|}{ Pyrosequencing } \\
\hline & & Methylated & Unmethylated & Methylated & Unmethylated \\
\hline Patients (n) & 58 & 19 & 39 & 29 & 29 \\
\hline Male/Female & $31 / 27$ & $10 / 9$ & $21 / 18$ & $15 / 14$ & $16 / 13$ \\
\hline $\begin{array}{l}\text { Mean age } \\
\text { (Standard deviation) }\end{array}$ & $\begin{array}{l}58.5 \\
(9.1)\end{array}$ & $\begin{array}{l}57.5 \\
(8.7)\end{array}$ & $\begin{array}{l}59.0 \\
(9.3)\end{array}$ & $\begin{array}{l}59.3 \\
(8.5)\end{array}$ & $\begin{array}{l}57.7 \\
(9.7)\end{array}$ \\
\hline $\begin{array}{l}\text { Median survival }\left.\right|^{\mathrm{b}} \\
\text { (Standard error) }\end{array}$ & $\begin{array}{l}13.1 \\
(1.1)\end{array}$ & $\begin{array}{l}17.6 \\
(4.2)\end{array}$ & $\begin{array}{l}12.2 \\
(1.0)\end{array}$ & $\begin{array}{l}16.1 \\
(3.7)\end{array}$ & $\begin{array}{l}11.5 \\
(0.4)\end{array}$ \\
\hline $\begin{array}{l}\text { 2-years overall survival (\%) } \\
\text { (Standard error) }\end{array}$ & $\begin{array}{c}21.8 \\
(0.06)\end{array}$ & $\begin{array}{c}35.5 \\
(0.11)\end{array}$ & $\begin{array}{l}15.4 \\
(0.06)\end{array}$ & $\begin{array}{c}33.6 \\
(0.09)\end{array}$ & $\begin{array}{l}10.3 \\
(0.06)\end{array}$ \\
\hline
\end{tabular}

a)Years; b) Months

values for scoring samples as methylation positive. The threshold values were determined so that all the meningiomas were scored as methylation negative. These benign tumors showed little (pyrosequencing, mean methylation range $1.39-1.55 \%$ ) to no (qMSP, PMR 0\% in both assays) MGMT promoter methylation, resulting in low threshold values, thus supporting the assumption that meningiomas are suitable alternatives to normal tissue samples for threshold determination. However, this should be confirmed by validation studies in independent sample series. Brain tissue from surgery in epileptic patients is an alternative to the meningioma tissue for establishing cutoff values.

In accordance with previous reports, our results show that the overall survival for patients with a methylated MGMT promoter is better than for patients with an unmethylated promoter [10,20,23,24]. The observed difference at 24 months was significant based on the pyrosequencing results but only borderline significant based on the qMSP results. The logrank test results indicate that both methylation detection methods are able to identify primary glioblastoma

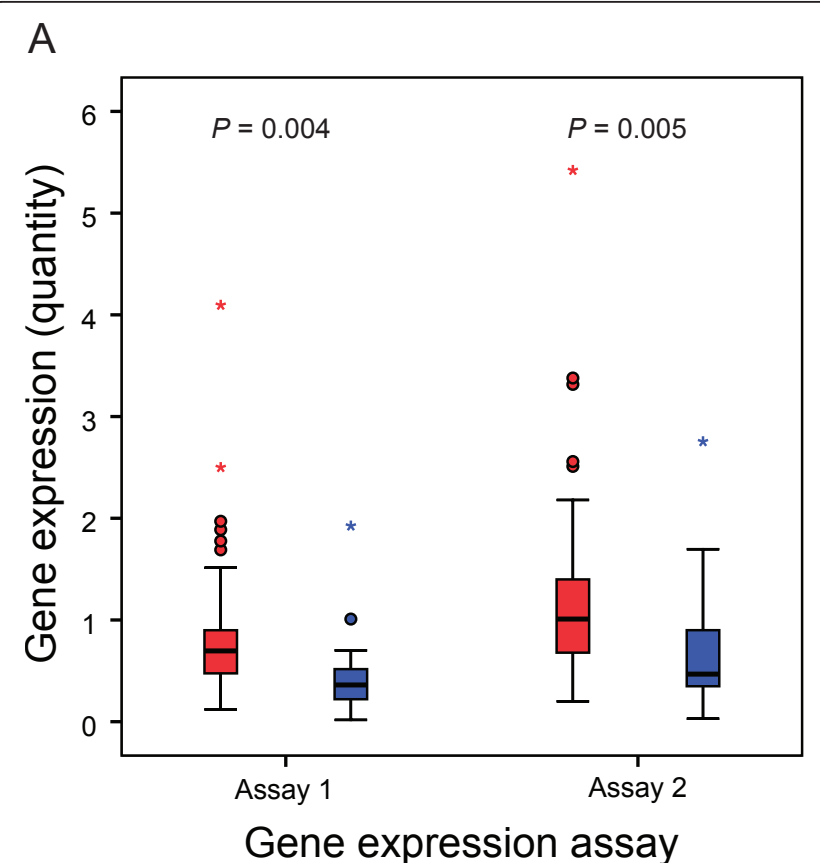

$\mathrm{B}$

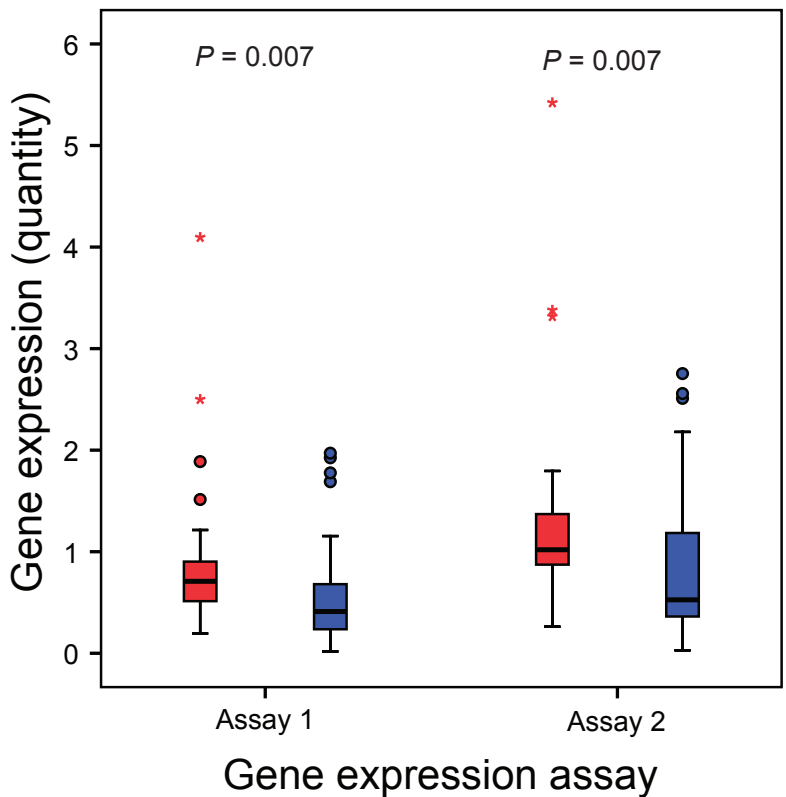

Figure 2 Gene expression level of MGMT is associated with promoter DNA methylation status. MGMT gene expression in methylated (blue box plots) and unmethylated (red box plots) tissue samples analyzed by two different primer/probe sets (Assay 1; Hs00172470_m1 and assay 2; Hs01037698_m1). (A) Methylation status based on results from gMSP. (B) Methylation status based on results from pyrosequencing. Abbreviation: qMSP, quantitative methylation specific PCR 


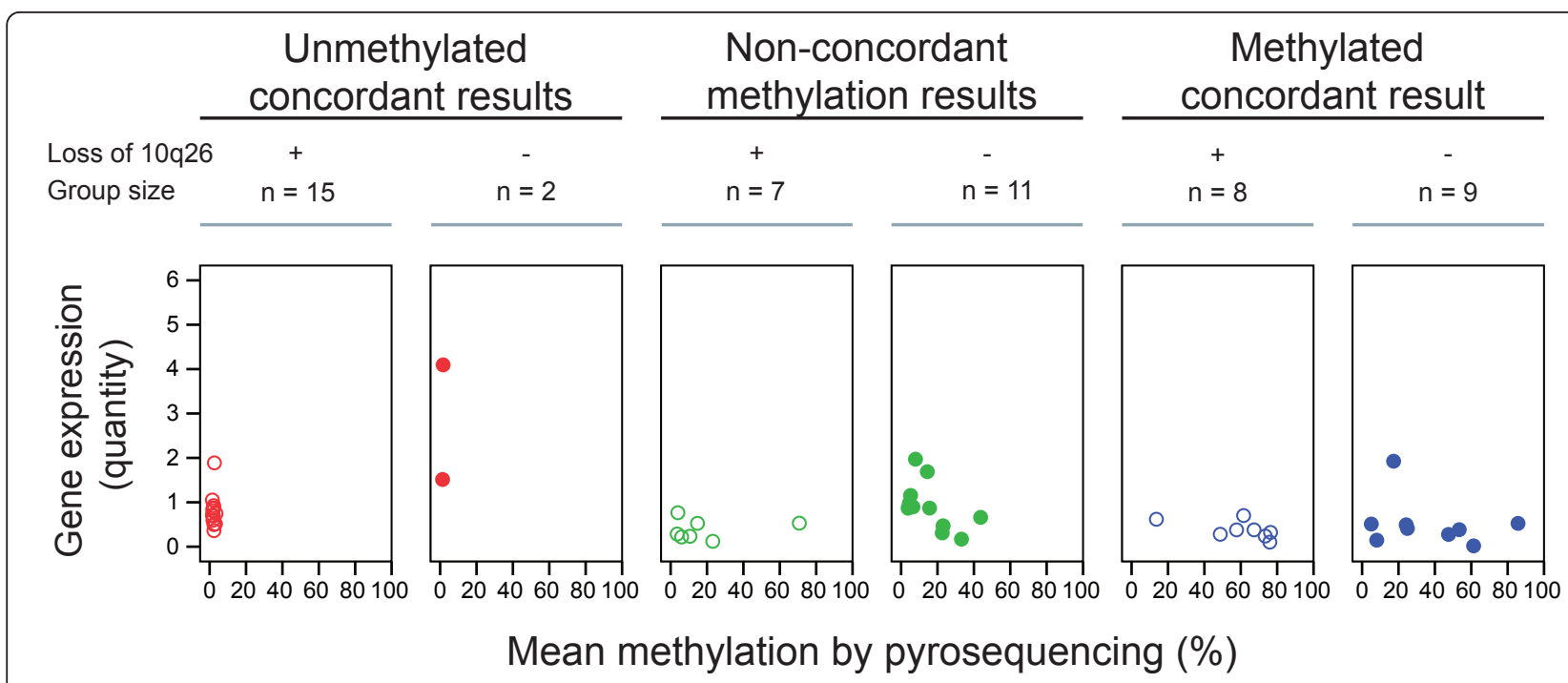

Figure 3 Scatter plots of MGMT gene expression quantity in methylated and unmethylated samples. Red color indicates samples with negative methylation status by GMSP and pyrosequencing, blue color indicates samples with positive methylation status by qMSP and pyrosequencing, and green color indicate samples with non-concordant methylation status in the qMSP and pyrosequencing analysis. Circles indicate samples with loss of 10q26, whereas dots represent samples without loss of this region. Plots are based on the normalized gene expression detected by primer/probe set Hs00172470_m1. The plots based on the normalized gene expression detected by the other primer/ probe set, Hs01037698_m1, were similar (data not shown). Abbreviation: qMSP, quantitative methylation specific PCR

patients with a somewhat better prognosis. However, the survival curve differences are more distinct when using the pyrosequencing based methylation status, implying that this is the better method to use for estimating the prognosis. These results are in line with the observation that the patients with non-concordant methylation findings (unmethylated by qMSP and methylated by pyrosequencing) showed a trend towards better survival than patients with unmethylated MGMT promoter by both methods (Figure 1C). The last mentioned finding should, however, be validated in an independent sample set. Nevertheless, based on the observations done here, it could be argued that a primary glioblastoma should be regarded MGMT promoter methylated if the pyrosequencing result is positive. Because all glioblastoma patients receive TMZ as part of the Stupp regimen, the methylation status of the $M G M T$ promoter does not change the therapeutic regime today. Nonetheless, it is a prognostic marker [11] of clinical interest and may be relevant for evaluation of pseudoprogression [24]. It is also interesting that, independent of the method used, the methylation level (amount of methylation) observed in methylation positive lowgrade gliomas is low compared to the level observed in methylation positive high-grade gliomas. This has not been reported previously and may in part explain the large difference in methylation frequency as assessed by qMSP and pyrosequencing in low-grade gliomas. The clinical relevance of this finding remains to be determined and the data should be validated in an independent data set. Nevertheless, the overall survival analysis, which includes GBM with a low methylation level, suggests that pyrosequencing is the better method for predicting prognosis in primary GBM patients. This may also suggest an advantage of a low methylation level in low-grade gliomas. There are not many studies reporting MGMT promoter methylation frequencies in large series of low-grade gliomas. However, two studies analyzing 68 and 185 low-grade gliomas report methylation frequencies of $93 \%$ and $81 \%$, respectively, using the same MSP primers in a nested two-stage approach $[18,25]$. These frequencies match our frequency (97\%) detected by the sensitive pyrosequencing approach. However, other studies with smaller sample series report lower frequencies in the range $40-50 \%$ [26-29] when analyzed by conventional MSP.

We found a significant association between MGMT promoter methylation and reduced gene expression, regardless of methylation detection method and gene expression assay used. Based on this, one could suggest that the gene expression level might be analyzed instead of promoter methylation. However, the gene expression level in methylated and unmethylated samples shows considerable overlap (Figure 2) which may be due to lack of a linear relationship between the region analyzed for promoter methylation and gene expression. The 
most commonly analyzed region in the $M G M T$ gene promoter covers 9 of the totally $97 \mathrm{CpG}$ sites in the promoter, and it has been suggested that methylation in some specific CpG sites correlates better with reduction in gene expression level than analysis of the common MSP region (Additional file 1: Figure S1) [30]. On the other hand, factors such as contamination with normal cells and loss of one MGMT allele may also influence the detected gene expression level. For a subset of the samples with gene expression data and methylation status, we had access to karyotypic and/or CGH data $[16,17]$ (author H-S. S. Dahlback, unpublished data). Figure 3 illustrates that the MGMT gene expression seemed to be affected by loss of the 10q26 chromosome band. Interestingly, but not unexpectedly, the loss of this chromosome band seemed to have a larger impact on gene expression in samples with a low methylation level (mean methylation by pyrosequencing $<20 \%$ ) compared to highly methylated samples. However, these observations are based on results from small groups and should be tested in a larger dataset.

It is important to keep in mind that it is the MGMT protein that counteracts the effect of TMZ by removing methyl adducts at the $\mathrm{O}^{6}$-position of guanine. A recent study using human tumor cell lines derived from glioblastomas and other tumors concluded that the response to TMZ is better predicted by MGMT protein expression than by promoter methylation status [31]. However, although cancer cell lines are useful models for the in vivo situation, findings should be validated in patient sample series, and so far immunohistochemical analyses of the MGMT protein level in human tumor samples have been inconclusive when correlated with patient outcome [32].

\section{Conclusions}

Taken together, our findings corroborate earlier conclusions that MGMT promoter methylation is of prognostic value for primary glioblastoma patients $[9,10,20,22,33]$, and this status is of interest for the patients, their relatives, and treating physicians. Therefore, in our opinion determination of MGMT promoter methylation status should be incorporated into standard management programs for patients with GBM. There is currently no "gold standard" for which technique to use for assessing clinically meaningful MGMT promoter methylation. In this study pyrosequencing came across as a slightly better method than qMSP when looking at the prognostic value of $M G M T$ promoter methylation status in primary glioblastomas. Both qMSP and pyrosequencing are easy to perform and high-throughput methods; the choice of method therefore becomes one based on utilitarian considerations.

\section{Additional material}

Additional file 1: Supplementary material [8-10,12-14,18-30,34-120] CpG sites in the MGMT promoter frequently analyzed for DNA methylation. Description of the criteria for inclusion. Studies of MGMT promoter methylation in high-grade gliomas-summary of methylation frequencies and methodological details. Studies of MGMT promoter methylation in low-grade gliomas-summary of methylation frequencies and methodological details.

\section{Acknowledgements}

This study is supported by grants from the Norwegian Cancer Society and has received additional funding from Oslo University Hospital and the University of Oslo. We thank Ingrid Louise Norman for technical assistance in the laboratory.

\section{Author details}

${ }^{1}$ Section for Cancer Cytogenetics, Institute for Medical Informatics, Oslo University Hospital-The Norwegian Radium Hospital, P.O. Box 4950 Nydalen, N-0424 Oslo, Norway. ${ }^{2}$ Department of Cancer Prevention, Institute for Cancer Research, Oslo University Hospital-The Norwegian Radium Hospital, Oslo, Norway. ${ }^{3}$ Centre for Cancer Biomedicine, Faculty of Medicine, University of Oslo, Oslo, Norway. ${ }^{4}$ Faculty of Medicine, University of Oslo, Oslo, Norway. ${ }^{5}$ Department of Oncology, Oslo University Hospital-The Norwegian Radium Hospital, Oslo, Norway. ${ }^{6}$ Department of Pathology, Oslo University HospitalRikshospitalet, Oslo, Norway. ${ }^{7}$ Department of Neurosurgery, Oslo University Hospital-Rikshospitalet, Oslo, Norway. ${ }^{8}$ Department of Neurosurgery, Oslo University Hospital-Ullevål Hospital, Oslo, Norway. ${ }^{9}$ Cancer stem cell innovation center, Oslo University Hospital, Oslo, Norway.

\section{Authors' contributions}

Authors GEL, PB, RAL, and SH were responsible for the study design. $\mathrm{EH}$ and TRM were responsible for collecting clinical samples. H-SSD collected and registered the patient consents. $\mathrm{ABH}, \mathrm{H}-\mathrm{SSD}$, and $\mathrm{PB}$ collected and organized the clinical data. DS reviewed the histological diagnoses. Authors $A B H, H H$, $\mathrm{GEL}$, and $\mathrm{MH}$ contributed in the laboratory work. $\mathrm{ABH}, \mathrm{GEL}, \mathrm{HH}, \mathrm{PB}, \mathrm{RAL}$, and $\mathrm{SH}$ contributed in the interpretation of the data. $\mathrm{ABH}$ drafted the manuscript and made the tabular literature summary included in the Additional file 1. All authors carefully revised the manuscript and approved the final version.

\section{Competing interests}

The authors declare that they have no competing interests.

Received: 19 September 2011 Accepted: 6 March 2012 Published: 6 March 2012

\section{References}

1. WHO classification of tumours of the central nervous system. Edited by: Louis DN, Ohgaki H, Wiestler OD, Cavenee WK. Lyon: IARC; , 4 2007:

2. Jansen M, Yip S, Louis DN: Molecular pathology in adult gliomas: diagnostic, prognostic, and predictive markers. Lancet Neurol 2010, 9:717-726.

3. Stupp R, Mason WP, van den Bent MJ, Weller M, Fisher B, Taphoorn MJ, Belanger K, Brandes AA, Marosi C, Bogdahn U, Curschmann J, Janzer RC, Ludwin SK, Gorlia T, Allgeier A, Lacombe D, Cairncross JG, Eisenhauer E, Mirimanoff RO: Radiotherapy plus concomitant and adjuvant temozolomide for glioblastoma. N Engl J Med 2005, 352:987-996.

4. Helseth $R$, Helseth E, Johannesen TB, Langberg CW, Lote K, Rønning P, Scheie D, Vik A, Meling TR: Overall survival, prognostic factors, and repeated surgery in a consecutive series of 516 patients with glioblastoma multiforme. Acta Neurol Scand 2010, 122:159-167.

5. Villano JL, Seery TE, Bressler LR: Temozolomide in malignant gliomas: current use and future targets. Cancer Chemother Pharmacol 2009, 64:647-655.

6. Hegi ME, Liu L, Herman JG, Stupp R, Wick W, Weller M, Mehta MP, Gilbert MR: Correlation of O6-methylguanine methyltransferase (MGMT) promoter methylation with clinical outcomes in glioblastoma and 
clinical strategies to modulate MGMT activity. J Clin Oncol 2008, 26:4189-4199.

7. Gerson SL: Clinical relevance of MGMT in the treatment of cancer. J Clin Oncol 2002, 20:2388-2399.

8. Esteller M, Garcia-Foncillas J, Andion E, Goodman SN, Hidalgo OF, Vanaclocha V, Baylin SB, Herman JG: Inactivation of the DNA-repair gene MGMT and the clinical response of gliomas to alkylating agents. N Engl J Med 2000, 343:1350-1354

9. Hegi ME, Diserens A-C, Godard S, Dietrich P-Y, Regli L, Ostermann S, Otten P, Van Melle G, de Tribolet N, Stupp R: Clinical trial substantiates the predictive value of 0-6-methylguanine-DNA methyltransferase promoter methylation in glioblastoma patients treated with temozolomide. Clin Cancer Res 2004, 10:1871-1874.

10. Hegi ME, Diserens A-C, Gorlia T, Hamou M-F, de Tribolet N, Weller M, Kros JM, Hainfellner JA, Mason W, Mariani L, Bromberg JE, Hau P, Mirimanoff RO, Cairncross JG, Janzer RC, Stupp R: MGMT gene silencing and benefit from temozolomide in glioblastoma. N Engl J Med 2005, 352:997-1003.

11. Weller M, Stupp R, Reifenberger G, Brandes AA, van den Bent MJ, Wick W, Hegi ME: MGMT promoter methylation in malignant gliomas: ready for personalized medicine? Nat Rev Neurol 2010, 6:39-51.

12. Esteller M, Hamilton SR, Burger PC, Baylin SB, Herman JG: Inactivation of the DNA repair gene O6-methylguanine-DNA methyltransferase by promoter hypermethylation is a common event in primary human neoplasia. Cancer Res 1999, 59:793-797.

13. Hoque MO, Begum S, Topaloglu O, Chatterjee A, Rosenbaum E, Van Criekinge W, Westra WH, Schoenberg M, Zahurak M, Goodman SN, Sidransky D: Quantitation of promoter methylation of multiple genes in urine DNA and bladder cancer detection. J Natl Cancer Inst 2006, 98:996-1004

14. Rivera AL, Pelloski CE, Gilbert MR, Colman H, De La Cruz C, Sulman EP, Bekele BN, Aldape KD: MGMT promoter methylation is predictive of response to radiotherapy and prognostic in the absence of adjuvant alkylating chemotherapy for glioblastoma. Neuro Oncol 2010, 12:116-121.

15. Weisenberger DJ, Campan M, Long TI, Kim M, Woods C, Fiala E, Ehrlich M, Laird PW: Analysis of repetitive element DNA methylation by MethyLight. Nucleic Acids Res 2005, 33:6823-6836.

16. Dahlback H-SS, Brandal P, Meling TR, Gorunova L, Scheie D, Heim S: Genomic aberrations in 80 cases of primary glioblastoma multiforme: Pathogenetic heterogeneity and putative cytogenetic pathways. Genes Chromosomes Cancer 2009, 48:908-924.

17. Dahlback H-SS, Gorunova L, Brandal P, Scheie D, Helseth E, Meling TR, Heim S: Genomic aberrations in diffuse low-grade gliomas. Genes Chromosomes Cancer 2011, 50:409-420.

18. Everhard S, Kaloshi $G$, Crinière $E$, Benouaich-Amiel A, Lejeune J, Marie $Y$, Sanson M, Kujas M, Mokhtari K, Hoang-Xuan K, Delattre JY, Thillet J: MGMT methylation: a marker of response to temozolomide in low-grade gliomas. Ann Neurol 2006, 60:740-743.

19. El Hindy N, Adamzik M, Lambertz N, Bachmann HS, Worm K, Egensperger R, Frey UH, Asgari S, Sure U, Siffert W, Sandalcioglu IE: Association of the GNB3 825T-allele with better survival in patients with glioblastoma multiforme. J Cancer Res Clin Oncol 2010, 136:1423-1429.

20. Weller M, Felsberg J, Hartmann C, Berger H, Steinbach JP, Schramm J, Westphal M, Schackert G, Simon M, Tonn JC, Heese O, Krex D, Nikkhah G Pietsch T, Wiestler O, Reifenberger G, von Deimling A, Loeffler M: Molecular predictors of progression-free and overall survival in patients with newly diagnosed glioblastoma: a prospective translational study of the German Glioma Network. J Clin Oncol 2009, 27:5743-5750.

21. Parrella P, la Torre A, Copetti M, Valori VM, Barbano R, Notarangelo A, Bisceglia M, Gallo AP, Balsamo T, Poeta ML, Carella M, Catapano D, Parisi S, Dallapiccola B, Maiello E, D'Angelo V, Fazio VM: High specificity of quantitative methylation-specific PCR analysis for MGMT promoter hypermethylation detection in gliomas. J Biomed Biotechnol 2009, 2009:531692.

22. Dunn J, Baborie A, Alam F, Joyce K, Moxham M, Sibson R, Crooks D, Husband D, Shenoy A, Brodbelt A, Wong H, Liloglou T, Haylock B, Walker C: Extent of MGMT promoter methylation correlates with outcome in glioblastomas given temozolomide and radiotherapy. Br J Cancer 2009, 101:124-131.

23. Brandes AA, Franceschi E, Tosoni A, Benevento F, Scopece L, Mazzocchi V, Bacci A, Agati R, Calbucci F, Ermani M: Temozolomide concomitant and adjuvant to radiotherapy in elderly patients with glioblastoma: correlation with MGMT promoter methylation status. Cancer 2009, 115:3512-3518

24. Brandes AA, Franceschi E, Tosoni A, Blatt V, Pession A, Tallini G, Bertorelle R, Bartolini S, Calbucci F, Andreoli A, Frezza G, Leonardi M, Spagnolli F, Ermani M: MGMT promoter methylation status can predict the incidence and outcome of pseudoprogression after concomitant radiochemotherapy in newly diagnosed glioblastoma patients. J Clin Oncol 2008, 26:2192-2197.

25. Houillier C, Wang X, Kaloshi G, Mokhtari K, Guillevin R, Laffaire J, Paris S, Boisselier B, Idbaih A, Laigle-Donadey F, Hoang-Xuan K, Sanson M, Delattre JY: IDH1 or IDH2 mutations predict longer survival and response to temozolomide in low-grade gliomas. Neurol 2010, 75:1560-1566.

26. Komine C, Watanabe T, Katayama Y, Yoshino A, Yokoyama T, Fukushima T: Promoter hypermethylation of the DNA repair gene O6-methylguanineDNA methyltransferase is an independent predictor of shortened progression free survival in patients with low-grade diffuse astrocytomas. Brain Pathol 2003, 13:176-184.

27. Kuo L-T, Kuo K-T, Lee M-J, Wei C-C, Scaravilli F, Tsai J-C, Tseng H-M, Kuo MF, Tu Y-K: Correlation among pathology, genetic and epigenetic profiles, and clinical outcome in oligodendroglial tumors. Int J Cancer 2009, 124:2872-2879

28. Nakamura M, Watanabe T, Yonekawa Y, Kleihues P, Ohgaki H: Promoter methylation of the DNA repair gene MGMT in astrocytomas is frequently associated with G:C - > A:T mutations of the TP53 tumor suppressor gene. Carcinogenesis 2001, 22:1715-1719.

29. Watanabe T, Nakamura M, Kros JM, Burkhard C, Yonekawa Y, Kleihues P, Ohgaki H: Phenotype versus genotype correlation in oligodendrogliomas and low-grade diffuse astrocytomas. Acta Neuropathol 2002, 103:267-275.

30. Everhard S, Tost J, El Abdalaoui H, Criniere E, Busato F, Marie Y, Gut IG, Sanson M, Mokhtari K, Laigle-Donadey F, Hoang-Xuan K, Delattre JY, Thillet J: Identification of regions correlating MGMT promoter methylation and gene expression in glioblastomas. Neuro Oncol 2009, 11:348-356.

31. van Nifterik KA, van den Berg J, van der Meide WF, Ameziane N, Wedekind LE, Steenbergen RD, Leenstra S, Lafleur MV, Slotman BJ, Stalpers LJ, Sminia P: Absence of the MGMT protein as well as methylation of the MGMT promoter predict the sensitivity for temozolomide. Br J Cancer 2010, 103:29-35

32. Preusser M: MGMT analysis at DNA, RNA and protein levels in glioblastoma tissue. Histol Histopathol 2009, 24:511-518.

33. Gorlia T, van den Bent MJ, Hegi ME, Mirimanoff RO, Weller M, Cairncross JG, Eisenhauer E, Belanger K, Brandes AA, Allgeier A, Lacombe D, Stupp R: Nomograms for predicting survival of patients with newly diagnosed glioblastoma: prognostic factor analysis of EORTC and NCIC trial 2698122981/CE.3. Lancet Oncol 2008, 9:29-38

34. Maxwell JA, Johnson SP, Quinn JA, McLendon RE, Ali-Osman F, Friedman AH, Herndon JE, Bierau K, Bigley J, Bigner DD, Friedman HS: Quantitative analysis of O6-alkylguanine-DNA alkyltransferase in malignant glioma. Mol Cancer Ther 2006, 5:2531-2539.

35. Ang C, Guiot M-C, Ramanakumar AV, Roberge D, Kavan P: Clinical significance of molecular biomarkers in glioblastoma. Can J Neurol SC 2010, 37:625-630

36. Balaña C, Ramirez JL, Taron M, Roussos Y, Ariza A, Ballester R, Sarries C, Mendez P, Sanchez JJ, Rosell R: O6-methyl-guanine-DNA methyltransferase methylation in serum and tumor DNA predicts response to 1,3-bis(2-chloroethyl)-1-nitrosourea but not to temozolamide plus cisplatin in glioblastoma multiforme. Clin Cancer Res 2003, 9:1461-1468.

37. Blanc JL, Wager M, Guilhot J, Kusy S, Bataille B, Chantereau T, Lapierre F, Larsen CJ, Karayan-Tapon L: Correlation of clinical features and methylation status of MGMT gene promoter in glioblastomas. $\lrcorner$ Neurooncol 2004, 68:275-283.

38. Brandes AA, Tosoni A, Cavallo G, Bertorelle R, Gioia V, Franceschi E, Biscuola M, Blatt V, Crino L, Ermani M: Temozolomide 3 weeks on and 1 week off as first-line therapy for recurrent glioblastoma: phase II study from gruppo italiano cooperativo di neuro-oncologia (GICNO). $\mathrm{Br} J$ Cancer 2006, 95:1155-1160

39. Brandes AA, Tosoni A, Cavallo G, Reni M, Franceschi E, Bonaldi L, Bertorelle R, Gardiman M, Ghimenton C, luzzolino P, Pession A, Blatt V 
Ermani M: Correlations between O6-methylguanine DNA methyltransferase promoter methylation status, $1 p$ and $19 q$ deletions, and response to temozolomide in anaplastic and recurrent oligodendroglioma: a prospective GICNO study. I Clin Oncol 2006, 24:4746-4753.

40. Brandes AA, Tosoni A, Franceschi E, Sotti G, Frezza G, Amista P, Morandi L, Spagnolli F, Ermani M: Recurrence pattern after temozolomide concomitant with and adjuvant to radiotherapy in newly diagnosed patients with glioblastoma: correlation With MGMT promoter methylation status. J Clin Oncol 2009, 27:1275-1279.

41. Brandes AA, Franceschi E, Tosoni A, Bartolini S, Bacci A, Agati R, Ghimenton C, Turazzi S, Talacchi A, Skrap M, Marucci G, Volpin L, Morandi L, Pizzolitto S, Gardiman M, Andreoli A, Calbucci F, Ermani M: O(6)methylguanine DNA-methyltransferase methylation status can change between first surgery for newly diagnosed glioblastoma and second surgery for recurrence: clinical implications. Neuro Oncol 2010, 12:283-288.

42. Brell M, Tortosa A, Verger E, Gil JM, Vinolas N, Villa S, Acebes JJ, Caral L, Pujol T, Ferrer I, Ribalta T, Graus F: Prognostic significance of O6methylguanine-DNA methyltransferase determined by promoter hypermethylation and immunohistochemical expression in anaplastic gliomas. Clin Cancer Res 2005, 11:5167--5174.

43. The Cancer Genome Atlas Research Network: Comprehensive genomic characterization defines human glioblastoma genes and core pathways. Nature 2008, 455:1061-1068.

44. Cankovic M, Mikkelsen T, Rosenblum ML, Zarbo RJ: A simplified laboratory validated assay for MGMT promoter hypermethylation analysis of glioma specimens from formalin-fixed paraffin-embedded tissue. Lab Invest 2007, 87:392-397.

45. Cao VT, Jung TY, Jung S, Jin SG, Moon KS, Kim IY, Kang SS, Park CS, Lee KH, Chae HJ: The correlation and prognostic significance of MGMT promoter methylation and MGMT protein in glioblastomas. Neurosurgery 2009, 65:866-875, discussion 875 .

46. Christmann M, Nagel G, Horn S, Krahn U, Wiewrodt D, Sommer C, Kaina B: MGMT activity, promoter methylation and immunohistochemistry of pretreatment and recurrent malignant gliomas: a comparative study on astrocytoma and glioblastoma. Int J Cancer 2010, 127:2106-2118.

47. Clarke JL, Iwamoto FM, Sul J, Panageas K, Lassman AB, DeAngelis LM, Hormigo A, Nolan CP, Gavrilovic I, Karimi S, Abrey LE: Randomized phase II trial of chemoradiotherapy followed by either dose-dense or metronomic temozolomide for newly diagnosed glioblastoma. J Clin Oncol 2009, 27:3861-3867.

48. Costa BM, Smith JS, Chen Y, Chen J, Phillips HS, Aldape KD, Zardo G, Nigro J, James CD, Fridlyand J, Reis RM, Costello JF: Reversing HOXA9 oncogene activation by PI3K inhibition: epigenetic mechanism and prognostic significance in human glioblastoma. Cancer Res 2010, 70:453-462.

49. Costa BM, Caeiro C, Guimarães I, Martinho O, Jaraquemada T, Augusto I, Castro L, Osorio L, Linhares P, Honavar M, Resende M, Braga F, Silva A, Pardal F, Amorim J, Nabico R, Almeida R, Alegria C, Pires M, Pinheiro C, Carvalho E, Lopes JM, Costa P, Damasceno M, Reis RM: Prognostic value of MGMT promoter methylation in glioblastoma patients treated with temozolomide-based chemoradiation: a Portuguese multicentre study. Oncol Rep 2010, 23:1655-1662.

50. Crinière E, Kaloshi G, Laigle-Donadey F, Lejeune J, Auger N, Benouaich-Amiel A, Everhard S, Mokhtari K, Polivka M, Delattre JY, Hoang-Xuan K, Thillet J, Sanson M: MGMT prognostic impact on glioblastoma is dependent on therapeutic modalities. J Neurooncol 2007, 83:173-179.

51. Drabycz S, Roldán G, de Robles P, Adler D, McIntyre JB, Magliocco AM, Cairncross JG, Mitchell JR: An analysis of image texture, tumor location, and MGMT promoter methylation in glioblastoma using magnetic resonance imaging. Neuroimage 2010, 49:1398-1405.

52. Ducray $F$, de Reyniès $A$, Chinot $\mathrm{O}$, Idbaih $\mathrm{A}$, Figarella-Branger $\mathrm{D}$, Colin $\mathrm{C}$, Karayan-Tapon L, Chneiweiss H, Wager M, Vallette F, Marie Y, Rickman D, Thomas E, Delattre JY, Honnorat J, Sanson M, Berger F: An ANOCEF genomic and transcriptomic microarray study of the response to radiotherapy or to alkylating first-line chemotherapy in glioblastoma patients. Mol Cancer 2010, 9:234.

53. Wick A, Felsberg J, Steinbach JP, Herrlinger U, Platten M, Blaschke B, Meyermann R, Reifenberger G, Weller M, Wick W: Efficacy and tolerability of temozolomide in an alternating weekly regimen in patients with recurrent glioma. J Clin Oncol 2007, 25:3357-3361.

54. Eoli M, Menghi F, Bruzzone MG, De Simone T, Valletta L, Pollo B, Bissola L, Silvani A, Bianchessi D, D'Incerti L, Filippini G, Broggi G, Boiardi A, Finocchiaro G: Methylation of O6-methylguanine DNA methyltransferase and loss of heterozygosity on 19q and/or 17p are overlapping features of secondary glioblastomas with prolonged survival. Clin Cancer Res 2007, 13:2606-2613.

55. Etcheverry A, Aubry M, de Tayrac M, Vauleon E, Boniface R, Guenot F, Saikali S, Hamlat A, Riffaud L, Menei P, Quillien V, Mosser J: DNA methylation in glioblastoma: impact on gene expression and clinical outcome. BMC Genomics 2010, 11:701.

56. Fabi A, Metro G, Vidiri A, Lanzetta G, Carosi M, Telera S, Maschio M, Russillo M, Sperduti I, Carapella CM, Cognetti F, Pace A: Low-dose fotemustine for recurrent malignant glioma: a multicenter phase II study. J Neurooncol 2010, 100:209-215.

57. Felsberg J, Rapp M, Loeser S, Fimmers R, Stummer W, Goeppert M, Steiger HJ, Friedensdorf B, Reifenberger G, Sabel MC: Prognostic significance of molecular markers and extent of resection in primary glioblastoma patients. Clin Cancer Res 2009, 15:6683-6693.

58. Gan HK, Rosenthal MA, Dowling A, Kalnins R, Algar E, Wong N, Benson A, Woods AM, Cher L: A phase II trial of primary temozolomide in patients with grade III oligodendroglial brain tumors. Neuro Oncol 2010, 12:500-507.

59. Gerstner ER, Yip S, Wang DL, Louis DN, lafrate AJ, Batchelor TT: MGMT methylation is a prognostic biomarker in elderly patients with newly diagnosed glioblastoma. Neurology 2009, 73:1509-1510.

60. Glas M, Happold C, Rieger J, Wiewrodt D, Bahr O, Steinbach JP, Wick W, Kortmann RD, Reifenberger $G$, Weller M, Herrlinger U: Long-term survival of patients with glioblastoma treated with radiotherapy and lomustine plus temozolomide. J Clin Oncol 2009, 27:1257-1261.

61. Gonzalez-Gomez P, Bello MJ, Arjona D, Lomas J, Alonso ME, De Campos JM, Vaquero J, Isla A, Gutierrez M, Rey JA: Promoter hypermethylation of multiple genes in astrocytic gliomas. Int J Oncol 2003, 22:601-608.

62. Grasbon-Frodl EM, Kreth FW, Ruiter M, Schnell O, Bise K, Felsberg J, Reifenberger G, Tonn JC, Kretzschmar HA: Intratumoral homogeneity of MGMT promoter hypermethylation as demonstrated in serial stereotactic specimens from anaplastic astrocytomas and glioblastomas. Int J Cancer 2007, 121:2458-2464.

63. Möllemann M, Wolter M, Felsberg J, Collins VP, Reifenberger G: Frequent promoter hypermethylation and low expression of the MGMT gene in oligodendroglial tumors. Int I Cancer 2005, 113:379-385.

64. Grossman SA, Ye X, Chamberlain M, Mikkelsen T, Batchelor T, Desideri S, Piantadosi S, Fisher J, Fine HA: Talampanel with standard radiation and temozolomide in patients with newly diagnosed glioblastoma: a multicenter phase II trial. J Clin Oncol 2009, 27:4155-4161.

65. Hervouet E, Debien E, Campion L, Charbord J, Menanteau J, Vallette FM, Cartron PF: Folate supplementation limits the aggressiveness of glioma via the remethylation of DNA repeats element and genes governing apoptosis and proliferation. Clin Cancer Res 2009, 15:3519-3529.

66. Ishii D, Natsume A, Wakabayashi T, Hatano H, Asano Y, Takeuchi H, Shimato S, Ito M, Fujii M, Yoshida J: Efficacy of temozolomide is correlated with $1 \mathrm{p}$ loss and methylation of the deoxyribonucleic acid repair gene MGMT in malignant gliomas. Neurol Med Chir (Tokyo) 2007, 47:341-349.

67. Jesien-Lewandowicz E, Jesionek-Kupnicka D, Zawlik I, Szybka M, KulczyckaWojdala D, Rieske P, Sieruta M, Jaskolski D, Och W, Skowronski W, Sikorska B, Potemski P, Papierz W, Liberski PP, Kordek R: High incidence of MGMT promoter methylation in primary glioblastomas without correlation with TP53 gene mutations. Cancer Genet Cytogenet 2009, 188:77-82.

68. Jeuken JWM, Cornelissen SJB, Vriezen M, Dekkers MMG, Errami A, Sijben A, Boots-Sprenger SHE, Wesseling P: MS-MLPA: an attractive alternative laboratory assay for robust, reliable, and semiquantitative detection of MGMT promoter hypermethylation in gliomas. Lab Invest 2007, 87:1055-1065

69. Kamiryo T, Tada K, Shiraishi S, Shinojima N, Kochi M, Ushio Y: Correlation between promoter hypermethylation of the O6-methylguaninedeoxyribonucleic acid methyltransferase gene and prognosis in patients with high-grade astrocytic tumors treated with surgery, radiotherapy, and 1-(4-amino-2-methyl-5-pyrimidinyl)methyl-3-(2-chloroethyl)-3nitrosourea-based chemotherapy. Neurosurgery 2004, 54:349-357. 
70. Karayan-Tapon L, Quillien V, Guilhot J, Wager M, Fromont G, Saikali S, Etcheverry A, Hamlat A, Loussouarn D, Campion L, Campone M, Vallette FM, Gratas-Rabbia-Re C: Prognostic value of O(6)-methylguanine-DNA methyltransferase status in glioblastoma patients, assessed by five different methods. J Neurooncol 2009.

71. Koos B, Peetz-Dienhart S, Riesmeier B, Fruhwald MC, Hasselblatt M: O(6)methylguanine-DNA methyltransferase (MGMT) promoter methylation is significantly less frequent in ependymal tumours as compared to malignant astrocytic gliomas. Neuropathol Appl Neurobiol 2010, 36:356-358.

72. Laffaire J, Everhard S, Idbaih A, Criniere E, Marie Y, de Reynies A, Schiappa R, Mokhtari K, Hoang-Xuan K, Sanson M, Delattre JY, Thillet J, Ducray F: Methylation profiling identifies 2 groups of gliomas according to their tumorigenesis. Neuro Oncol 2011, 13:84-98.

73. Widschwendter M, Siegmund KD, Müller HM, Fiegl H, Marth C, MullerHolzner E, Jones PA, Laird PW: Association of breast cancer DNA methylation profiles with hormone receptor status and response to tamoxifen. Cancer Res 2004, 64:3807-3813.

74. Lai A, Tran A, Nghiemphu PL, Pope WB, Solis OE, Selch M, Filka E, Yong WH, Mischel PS, Liau LM, Phuphanich S, Black K, Peak S, Green RM, Spier CE, Kolevska T, Polikoff J, Fehrenbacher L, Elashoff R, Cloughesy T: Phase II study of bevacizumab plus temozolomide during and after radiation therapy for patients with newly diagnosed glioblastoma multiforme. $J$ Clin Oncol 2011, 29:142-148.

75. Lavon I, Refael M, Zelikovitch B, Shalom E, Siegal T: Serum DNA can define tumor-specific genetic and epigenetic markers in gliomas of various grades. Neuro Oncol 2010, 12:173-180

76. Levner I, Drabycz S, Roldan G, De Robles P, Cairncross JG, Mitchell R: Predicting MGMT methylation status of glioblastomas from MRI texture. Med Image Comput Comput Assist Interv 2009, 12:522-530.

77. Liu B-L, Cheng J-X, Zhang W, Zhang X, Wang R, Lin H, Huo J-L, Cheng H: Quantitative detection of multiple gene promoter hypermethylation in tumor tissue, serum, and cerebrospinal fluid predicts prognosis of malignant gliomas. Neuro Oncol 2010, 12:540-548

78. Lorente A, Mueller W, Urdangarín E, Lazcoz P, Lass U, von Deimling A Castresana JS: RASSF1A, BLU, NORE1A, PTEN and MGMT expression and promoter methylation in gliomas and glioma cell lines and evidence of deregulated expression of de novo DNMTs. Brain Pathol 2009, 19:279-292.

79. Martinez R, Schackert G, Yaya-Tur R, Rojas-Marcos I, Herman JG, Esteller M: Frequent hypermethylation of the DNA repair gene MGMT in long-term survivors of glioblastoma multiforme. J Neurooncol 2007, 83:91-93.

80. Martinez R, Martin-Subero Jl, Rohde V, Kirsch M, Alaminos M, Fernandez AF, Ropero S, Schackert G, Esteller M: A microarray-based DNA methylation study of glioblastoma multiforme. Epigenetics 2009, 4:255-264.

81. Martini M, Pallini R, Luongo G, Cenci T, Lucantoni C, Larocca LM: Prognostic relevance of SOCS3 hypermethylation in patients with glioblastoma multiforme. Int J Cancer 2008, 123:2955-2960.

82. Mellai M, Caldera V, Annovazzi L, Chio A, Lanotte M, Cassoni $P$, Finocchiaro G, Schiffer D: MGMT promoter hypermethylation in a series of 104 glioblastomas. Cancer Genomics Proteomics 2009, 6:219-227.

83. Metellus P, Coulibaly B, Nanni I, Fina F, Eudes N, Giorgi R, Barrie M, Chinot O, Fuentes S, Dufour H, Ouafik L, Figarella-Branger D: Prognostic impact of O6-methylguanine-DNA methyltransferase silencing in patients with recurrent glioblastoma multiforme who undergo surgery and carmustine wafer implantation: a prospective patient cohort. Cancer 2009, 115:4783-4794.

84. Mikeska T, Bock C, El-Maarri O, Hubner A, Ehrentraut D, Schramm J, Felsberg J, Kahl P, Buttner R, Pietsch T, Waha A: Optimization of quantitative MGMT promoter methylation analysis using pyrosequencing and combined bisulfite restriction analysis. J Mol Diagn 2007, 9:368-381.

85. Mikkelsen T, Doyle T, Anderson J, Margolis J, Paleologos N, Gutierrez J, Croteau D, Hasselbach L, Avedissian R, Schultz L: Temozolomide singleagent chemotherapy for newly diagnosed anaplastic oligodendroglioma. J Neurooncol 2009, 92:57-63.

86. Minniti G, Amelio D, Amichetti M, Salvati M, Muni R, Bozzao A, Lanzetta G, Scarpino S, Arcella A, Enrici RM: Patterns of failure and comparison of different target volume delineations in patients with glioblastoma treated with conformal radiotherapy plus concomitant and adjuvant temozolomide. Radiother Oncol 2010, 97:377-381.

87. Morandi L, Franceschi E, de Biase D, Marucci G, Tosoni A, Ermani M, Pession A, Tallini G, Brandes A: Promoter methylation analysis of O6-
methylguanine-DNA methyltransferase in glioblastoma: detection by locked nucleic acid based quantitative PCR using an imprinted gene (SNURF) as a reference. BMC Cancer 2010, 10:48.

88. Park C-K, Park S-H, Lee S-H, Kim C-Y, Kim D-W, Paek SH, Kim DG, Heo DS, Kim $\mathrm{IH}$, Jung H-W: Methylation status of the MGMT gene promoter fails to predict the clinical outcome of glioblastoma patients treated with ACNU plus cisplatin. Neuropathology 2009, 29:443-449.

89. Paz MF, Yaya-Tur R, Rojas-Marcos I, Reynes G, Pollan M, Aguirre-Cruz L, Garcia-Lopez JL, Piquer J, Safont MJ, Balana C, Sanchez-Cespedes M, GarciaVillanueva M, Arribas L, Esteller M: CpG island hypermethylation of the DNA repair enzyme methyltransferase predicts response to temozolomide in primary gliomas. Clin Cancer Res 2004, 10:4933-4938.

90. Piccirilli M, Bistazzoni S, Gagliardi FM, Landi A, Santoro A, Giangaspero F, Salvati M: Treatment of glioblastoma multiforme in elderly patients. Clinico-therapeutic remarks in 22 patients older than 80 years. Tumori 2006, 92:98-103.

91. Pirtoli L, Cevenini G, Tini P, Vannini M, Oliveri G, Marsili S, Mourmouras V, Rubino G, Miracco C: The prognostic role of Beclin 1 protein expression in high-grade gliomas. Autophagy 2009, 5:930-936.

92. Prados MD, Chang SM, Butowski N, DeBoer R, Parvataneni R, Carliner $H$, Kabuubi P, Ayers-Ringler J, Rabbitt J, Page M, Fedoroff A, Sneed PK, Berger MS, McDermott MW, Parsa AT, Vandenberg S, James CD, Lamborn KR, Stokoe D, Haas-Kogan DA: Phase II study of erlotinib plus temozolomide during and after radiation therapy in patients with newly diagnosed glioblastoma multiforme or gliosarcoma. J Clin Oncol 2009, 27:579-584.

93. Ramirez UL, Taron M, Balaña C, Sarries C, Mendez P, de Aguirre I, Nunez L, Roig B, Queralt C, Botia M, Rosell R: Serum DNA as a tool for cancer patient management. Rocz Akad Med Bialymst 2003, 48:34-41.

94. Rodriguez FJ, Thibodeau SN, Jenkins RB, Schowalter KV, Caron BL, O'Neill BP, James CD, Passe S, Slezak J, Giannini C: MGMT immunohistochemical expression and promoter methylation in human glioblastoma. Appl Immunohistochem Mol Morphol 2008, 16:59-65.

95. Sadones J, Michotte A, Veld P, Chaskis C, Sciot R, Menten J, Joossens EJ, Strauven T, D'Hondt LA, Sartenaer D, Califice SF, Bierau K, Svensson C, De Greve J, Neyns B: MGMT promoter hypermethylation correlates with a survival benefit from temozolomide in patients with recurrent anaplastic astrocytoma but not glioblastoma. Eur J Cancer 2009, 45:146-153.

96. Schaich M, Kestel L, Pfirrmann M, Robel K, Illmer T, Kramer M, Dill C, Ehninger $G$, Schackert G, Krex D: A MDR1 (ABCB1) gene single nucleotide polymorphism predicts outcome of temozolomide treatment in glioblastoma patients. Ann Oncol 2009, 20:175-181.

97. Shamsara J, Sharif S, Afsharnezhad S, Lotfi M, Raziee HR, Ghaffarzadegan K, Moradi A, Rahighi S, Behravan J: Association between MGMT promoter hypermethylation and p53 mutation in glioblastoma. Cancer Invest 2009 27:825-829.

98. Sijben AE, McIntyre JB, Roldán GB, Easaw JC, Yan E, Forsyth PA, Parney IF, Magliocco AM, Bernsen H, Cairncross JG: Toxicity from chemoradiotherapy in older patients with glioblastoma multiforme. J Neurooncol 2008, 89:97-103.

99. Slaby O, Lakomy R, Fadrus P, Hrstka R, Kren L, Lzicarova E, Smrcka M, Svoboda M, Dolezalova H, Novakova J, Valik D, Vyzula R, Michalek J: MicroRNA-181 family predicts response to concomitant chemoradiotherapy with temozolomide in glioblastoma patients. Neoplasma 2010, 57:264-269.

100. Smith KA, Ashby LS, Gonzalez LF, Brachman DG, Thomas T, Coons SW Battaglia M, Scheck A: Prospective trial of gross-total resection with Gliadel wafers followed by early postoperative Gamma Knife radiosurgery and conformal fractionated radiotherapy as the initial treatment for patients with radiographically suspected, newly diagnosed glioblastoma multiforme. J Neurosurg 2008, 109:106-117.

101. Sonoda Y, Kumabe T, Watanabe M, Nakazato Y, Inoue T, Kanamori M, Tominaga T: Long-term survivors of glioblastoma: clinical features and molecular analysis. Acta Neurochir (Wien) 2009, 151:1349-1358.

102. Sonoda Y, Yokosawa M, Saito R, Kanamori M, Yamashita Y, Kumabe T, Watanabe M, Tominaga T: O(6)-Methylguanine DNA methyltransferase determined by promoter hypermethylation and immunohistochemical expression is correlated with progression-free survival in patients with glioblastoma. Int J Clin Oncol 2010, 15:352-358.

103. Spiegl-Kreinecker S, Pirker C, Filipits M, Lotsch D, Buchroithner J, Pichler J, Silye R, Weis S, Micksche M, Fischer J, Berger W: O6-Methylguanine DNA 
methyltransferase protein expression in tumor cells predicts outcome of temozolomide therapy in glioblastoma patients. Neuro Oncol 2010, 12:28-36.

104. Stupp R, Hegi ME, Neyns B, Goldbrunner R, Schlegel U, Clement PM, Grabenbauer GG, Ochsenbein AF, Simon M, Dietrich PY, Pietsch T, Hicking C, Tonn JC, Diserens AC, Pica A, Hermisson M, Krueger S, Picard M, Weller M: Phase I/lla study of cilengitide and temozolomide with concomitant radiotherapy followed by cilengitide and temozolomide maintenance therapy in patients with newly diagnosed glioblastoma. $J$ Clin Oncol 2010, 28:2712-2718.

105. van den Bent MJ, Dubbink HJ, Sanson M, van der Lee-Haarloo CR, Hegi M, Jeuken JW, Ibdaih A, Brandes AA, Taphoorn MJ, Frenay M, Lacombe D, Gorlia T, Dinjens WN, Kros JM: MGMT promoter methylation is prognostic but not predictive for outcome to adjuvant PCV chemotherapy in anaplastic oligodendroglial tumors: a report from EORTC Brain Tumor Group Study 26951. J Clin Oncol 2009, 27:5881-5886.

106. Vogelbaum MA, Berkey B, Peereboom D, Macdonald D, Giannini C, Suh JH, Jenkins R, Herman J, Brown P, Blumenthal DT, Biggs C, Schultz C, Mehta M: Phase II trial of preirradiation and concurrent temozolomide in patients with newly diagnosed anaplastic oligodendrogliomas and mixed anaplastic oligoastrocytomas: RTOG BR0131. Neuro Oncol 2009, 11:167-175.

107. Watanabe T, Katayama Y, Komine C, Yoshino A, Ogino A, Ohta T, Fukushima T: O6-methylguanine-DNA methyltransferase methylation and TP53 mutation in malignant astrocytomas and their relationships with clinical course. Int J Cancer 2005, 113:581-587.

108. Watanabe T, Katayama Y, Ogino A, Ohta T, Yoshino A, Fukushima T: Preliminary individualized chemotherapy for malignant astrocytomas based on 06-methylguanine-deoxyribonucleic acid methyltransferase methylation analysis. Neurol Med Chir (Tokyo) 2006, 46:387-393.

109. Weiler M, Hartmann C, Wiewrodt D, Herrlinger U, Gorlia T, Bahr O, Meyermann R, Bamberg M, Tatagiba M, von Deimling A, Weller M, Wick W: Chemoradiotherapy of newly diagnosed glioblastoma with intensified temozolomide. Int J Radiat Oncol Biol Phys 2010, 77:670-676.

110. Wemmert S, Bettscheider M, Alt S, Ketter R, Kammers K, Feiden W, Steudel WI, Rahnenfuhrer J, Urbschat S: p15 promoter methylation - a novel prognostic marker in glioblastoma patients. Int J Oncol 2009, 34:1743-1748.

111. Wick W, Hartmann C, Engel C, Stoffels M, Felsberg J, Stockhammer F, Sabel MC, Koeppen S, Ketter R, Meyermann R, Rapp M, Meisner C, Kortmann RD, Pietsch T, Wiestler OD, Ernemann U, Bamberg M, Reifenberger G, von Deimling A, Weller M: NOA-04 randomized phase III trial of sequential radiochemotherapy of anaplastic glioma with procarbazine, lomustine, and vincristine or temozolomide. J Clin Oncol 2009, 27:5874-5880.

112. Yachi K, Watanabe T, Ohta T, Fukushima T, Yoshino A, Ogino A, Katayama $Y$, Nagase H: Relevance of MSP assay for the detection of MGMT promoter hypermethylation in glioblastomas. Int J Oncol 2008, 33:469-475.

113. Yang S-H, Kim YH, Kim JW, Park C-K, Park S-H, Jung H-W: Methylation Status of the O6-Methylguanine-Deoxyribonucleic Acid Methyltransferase Gene Promoter in World Health Organization Grade III Gliomas. J Korean Neurosurg Soc 2009, 46:385-388.

114. Zawlik I, Vaccarella S, Kita D, Mittelbronn M, Franceschi S, Ohgaki H: Promoter methylation and polymorphisms of the MGMT gene in glioblastomas: a population-based study. Neuroepidemiology 2009, 32:21-29.

115. Palmisano WA, Divine KK, Saccomanno G, Gilliland FD, Baylin SB, Herman JG, Belinsky SA: Predicting lung cancer by detecting aberrant promoter methylation in sputum. Cancer Res 2000, 60:5954-5958.

116. van Engeland M, Weijenberg MP, Roemen GMJM, Brink M, de Bruine AP, Goldbohm RA, van den Brandt PA, Baylin SB, de Goeij AF, Herman JG: Effects of dietary folate and alcohol intake on promoter methylation in sporadic colorectal cancer: the Netherlands cohort study on diet and cancer. Cancer Res 2003, 63:3133-3137.

117. Alonso ME, Bello MJ, Gonzalez-Gomez P, Arjona D, Lomas J, de Campos JM, Isla A, Sarasa JL, Rey JA: Aberrant promoter methylation of multiple genes in oligodendrogliomas and ependymomas. Cancer Genet Cytogenet 2003, 144:134-142

118. Dong S-M, Pang JS-S, Poon W-S, Hu J, To K-F, Chang AR, Ng H-K: Concurrent hypermethylation of multiple genes is associated with grade of oligodendroglial tumors. J Neuropathol Exp Neurol 2001, 60:808-816.
119. Kesari S, Schiff D, Drappatz J, LaFrankie D, Doherty L, Macklin EA, Muzikansky A, Santagata S, Ligon KL, Norden AD, Ciampa A, Bradshaw J, Levy B, Radakovic G, Ramakrishna N, Black PM, Wen PY: Phase II study of protracted daily temozolomide for low-grade gliomas in adults. Clin Cancer Res 2009, 15:330-337.

120. Tosoni A, Franceschi E, Ermani M, Bertorelle R, Bonaldi L, Blatt V, Brandes AA: Temozolomide three weeks on and one week off as first line therapy for patients with recurrent or progressive low grade gliomas. J Neurooncol 2008, 89:179-185.

doi:10.1186/1479-5876-10-36

Cite this article as: Håvik et al:: MGMT promoter methylation in gliomasassessment by pyrosequencing and quantitative methylation-specific PCR. Journal of Translational Medicine 2012 10:36.

\section{Submit your next manuscript to BioMed Central and take full advantage of:}

- Convenient online submission

- Thorough peer review

- No space constraints or color figure charges

- Immediate publication on acceptance

- Inclusion in PubMed, CAS, Scopus and Google Scholar

- Research which is freely available for redistribution

Submit your manuscript at www.biomedcentral.com/submit
Biomed Central 